DOI: 10.22616/REEP.2021.14.019

\title{
Exploring Brand Personality in Higher Education
}

\author{
Antra Roskosa ${ }^{1}$ Dr. sc. admin.; (D) Yulia Stukalina ${ }^{2}$ Dr. sc. admin. \\ Riga Technical University, Latvia ${ }^{1}$; Transport and Telecommunication Institute, Latvia ${ }^{2}$ \\ Antra.Roskosa@rtu.lv¹; Stukalina.J@tsi.lv²
}

\begin{abstract}
The increasing role of branding in the higher education sector is closely associated with the enhanced marketing orientation of a modern university. This, in turn, is determined by intensified competition between higher education institutions for students, staff, sponsors and research funding. A strong university's brand related to excellent academic reputation can become a means for gaining competitive advantage in the global education marketplace. Brand is regarded as a complex concept comprising different constituents, brand image being an essential branding facet. Brand image is linked to customers' perceptions of a brand that are echoed by a set of brand associations - usage situations, product attributes and brand personality. The aim of the paper is to explore brand personality in higher education based on the data collected in two tertiary education institutions - RTU (Riga Technical University) and TSI (Transport and Telecommunication Institute). The study makes use of the conceptual customer-based brand equity model (CBBE) created by K.L. Keller, which assumes that brand equity is closely related to strong positive and exclusive brand associations that can be expressed as brand benefits, attitudes and attributes, brand personality attributes being an essential aspect of brand equity. For exploring brand personality, the paper also applies the brand personality framework, including brand personality dimensions and associated attributes, developed by J.L. Aaker. The paper reports the results of a survey used to collect information about RTU and TSI students' perceptions of different brand personality attributes. The results of the empirical study demonstrate that every university is recommended to be tolerant, open-minded and respected. The base of it lies on the same ground - the respect towards the personality. Moreover, every university is also recommended to become a "modern brand", innovation, creativity and thinking "out of the box" being essential characteristics of the brand. The results of the study would contribute to overall understanding of brand personality in higher education, and how it may influence preference for a brand in educational settings.
\end{abstract}

Keywords: university education, brand equity, brand associations, brand personality attributes.

\section{Introduction}

Nowadays, the growing role of branding in the higher education area is widely acknowledged, which is closely associated with increased marketing orientation of universities that are trying to adapt to the extremely competitive national and international education markets (Hemsley-Brown, Oplatka, 2006; Maringe, 2006; Stensaker, D’Andrea, 2007; Wæraas, Solbakk, 2009; Wu, Naidoo, 2016; Hemsley-Brown et al., 2016). Modern students are supposed to possess the so-called "consumerist approach" to choosing a university, which is determined by the importance they attach to their career prospects (Maringe, 2006).

Currently, European higher education institutions are made to reorganize to perform as businesses in an extremely competitive environment (Mampaey, Huisman, 2016). The higher education sector is gradually marketized, branding is now accepted by many universities as a strategy to distinguish it from it rivals in the agenda of intensified competition for students, staff and funding. (Clark, Chapleo, Suomi, 2020). Branding in this area is becoming a "routine" (Stukalina, 2019); branding activities related to differentiation are now in the focus of senior educational managers' efforts (Chapleo, 2010). J. Mampaey and J. Huisman (2016) define branding in tertiary education as the enhancement of academia with organizational values and their presentation to the external environment; in this regard, branding is closely related to image management. Universities have to put more emphasis on building and promoting their brands for inducing encouraging associations with diverse stakeholder groups; students are viewed as their key "customers" (Roskosa, Stukalina, 2020) and the most interested "party" as to educational "products" (Roskosa, Stukalina, 2018). A powerful university's brand can reinforce the credibility of a higher education institution (Kotler, Keller, 2016) in the highly competitive business environment.

Brands can be considered from different perspectives (Kotler, Keller, 2012). Consumers' perceptions of a brand may be expressed by an assortment of brand associations (Keller, 1993; 2013), which are used for 
differentiating and positioning a brand (Low, Lamb, 2000). Brand personality attributes represent one aspect of brand associations associated with the feelings induced by a particular brand (Keller, 1993).

The aim of the paper is to explore brand personality in higher education based on the data collected in two tertiary education institutions - Riga Technical University (RTU) and Transport and Telecommunication Institute (TSI).

\section{Methodology}

The methodology used in the paper includes the review of theoretical literature and prior research on brand management, and a survey performed in two institutions of higher education.

The study uses the conceptual customer-based brand equity model (CBBE) proposed by K.L. Keller (2001; 2007; 2008; 2009), which assumes that brand equity is closely related to strong positive and exclusive brand associations expressed as brand benefits, attitudes and attributes, brand personality attributes being an essential aspect of brand equity. For exploring brand personality, the paper also applies the brand personality framework, including brand personality dimensions and associated attributes developed by J.L. Aaker (1997), which appears to be relevant in the higher education settings.

An original questionnaire was developed for gathering empirical information about brand personality attributes. Brand personality was measured applying the five-dimension scale proposed by J.L. Aaker (1997) that was adapted to the purpose of the study and included such elements as (in the order mentioned) Sincerity, Excitement, Competence, Sophistication and Ruggedness. Every dimension was associated with three personality attributes. In general, the questionnaire contained fifteen items associated with the above dimensions: $Q 1$. My university is accessible for students; $Q 2$. I can characterize my university to be honest; $Q 3$. I believe my university is student-oriented; $Q 4$. My university is inspiring; Q5. I evaluate my university to be up to date; Q6. I think my university is extraordinary; Q7. My university is open-minded; $Q 8$. I can characterize my university to be tolerant; $Q 9$. I consider my university to be respected; Q10. I evaluate my university to be upper-class; Q11. I think my university is attractive; Q12. I can characterize my university as innovative; Q13. I believe my university is reliable; Q14. My university is intelligent; Q15. I evaluate my university to be successful.

The response format was a three-point Likert scale - "disagree", "neither agree nor disagree", and "agree". The survey was conducted in Riga Technical University and Transport and Telecommunication Institute in September - October 2020. The population of the research included 64 RTU students and 93 TSI students of the following directions: Information Technologies, Transport and Engineering, Management and Economics. The data were then processed by means of Excel tools.

\section{Results and Discussion}

\section{Literature review: Brand management and associated concepts}

In the modern business environment, brand management is an important marketing concern (Keller, 2009; Kotler, Keller, 2012; Kotler, Keller, 2016). The classic brand management model is now transformed into the brand leadership model having a strategic perspective, which puts more emphasis on brand equity in the agenda of building a strong brand (Aaker, 2012). Brand is regarded as a multifaceted concept; thus, there are different approaches to this construct, as well as different models describing brand constituents. A holistic understanding of a brand presumes that diverse brand-building elements should be considered, the obtained information being employed in for reviewing branding strategies (Roskosa, Stukalina, 2020). Brand components can take different forms (Kotler, Keller, 2012), brand image being an essential marketing concept to be considered. K.L. Keller (1993) describes the brand images as similar to perceptions about a certain brand "reproduced" by some brand associations in the user's memory and linked to the meaning of this brand; their strength and inimitability are central to shaping the "differential response" that composes brand equity. Brand image is an essential branding facet that is linked to consumers' perceptions of a brand that are reflected by a set of brand associations including usage situations, product attributes and brand personality (Keller, 1993; 2001; 2013). Brand management includes determining what brand associations to develop, which will be reflected in branding strategies (Aaker, Joachimsthaler, 2012). According to K.L. Keller (1993; 2013), brand associations encompass the meaning of the brand for its users (consumers). They are either produced from a consumer's experience - that is directly or through exchange of information 
among consumers and brand advertising - that is indirectly. So, establishing a brand image presupposes generating a variety of brand associations - what this particular brand is symbolized in the minds of its users (Keller, 2001). As stated by J.L. Aaker (1997), brand associations embrace anything, which is connected with a particular brand in consumers' memory. Although there are lots of brand associations, they can be categorized as connected with a) brand performance - how the brand satisfies functional needs of its consumers; b) brand imagery - rather than an aesthetic aspect (Keller, 2001).

Brand associations are descriptive features (qualitative in nature) that take a variety of forms (Keller, 1993). Brand associations are determined by brand identity - that is what an organization wishes to induce in customers' memory (Aaker, 2011). Marketers employ brand associations for brand differentiating brands and brand positioning, which is related to generating positive attitudes and feelings toward a brand (Low, Lamb, 2000). A complete understanding of brand associations would also be beneficial for developing brand extension strategies that are intended for reassigning particular attributes from a present brand to a new-fangled product (Aaker, Keller, 1990); in higher education, for example, it is associated with introducing new educational programmes and courses. In the CBBE K.L. Keller (2001; 2008; 2009), it is assumed that brand associations are expressed as brand benefits, attitudes and attributes, brand personality attributes being a vital aspect of brand equity. Brand personality as an element of brand image (Plummer, 2000) is an assortment of human features related to the brand (Aaker, 1997). Brand personality attributes "echo" those feelings, which are induced by this brand (Keller, 1993).

J.L. Aaker's (1997) multi-dimensional brand personality construct was developed from a factor analysis of the survey data related to the most well-known brands. It includes five dimensions allied with brand personality that can be used generalized across different product categories and cultures, the five-factor solution being easily interpretable; this brand personality scale bears a resemblance to a human personality scale, which would make it easier to develop the "right" brand personality from the point of view of a consume (Aaker, 1997). It should be also noted that human personality was habitually mentioned as the theory, which can also be applicable to brand personality (Davies et al., 2018). Although some authors have criticized Aaker, indicating the scale's large dependence on cultural context, this framework seems to be rather flexible and easily manageable. That is why many researchers have already applied it through various products for measuring the brand personality in five central dimensions that embrace forty-two aspects (Tong, $\mathrm{Su}, \mathrm{Xu}, 2018$ ). However, in higher education this approach has not been widely used yet. In the paper, Aaker's brand personality dimensions are represented by a set of brand attributes that may be associated with a university, and which appear to be relevant in higher education settings (Table 1).

Table 1

Brand personality dimensions and related brand attributes (adapted from J.L. Aaker (1997))

\begin{tabular}{|c|l|l|}
\hline No. & Brand personality dimension & Associated brand personality attributes \\
\hline 1 & Sincerity & Accessible, Honest, Student-oriented \\
\hline 2 & Excitement & Inspiring, Up-to-date, Extraordinary \\
\hline 3 & Ruggedness & Open-minded, Tolerant, Respected \\
\hline 4 & Sophistication & Upper-class, Attractive, Innovative \\
\hline 5 & Competence & Reliable, Intelligent, Successful \\
\hline
\end{tabular}

J.L. Aaker's multi-dimensional construct offers theoretical insights into why consumers buy brands, as it is related to purchasing decisions (Aaker, 1997). Being a cross-category framework in nature, it could help higher education marketing managers to understand why students "have their heart set" on a particular university.

\section{Analysis of the empirical study results}

The empirical research results are presented in Table 2, Figure 1 and Figure 2.

The first brand dimension evaluated by the students was sincerity. The data show that both groups of students have assessed this dimension quite similarly. As seen from Table 2, $81 \%$ of RTU students and $80 \%$ of TSI students have agreed that their university is accessible, honest and student-oriented. Only $16 \%$ of RTU students and $15 \%$ of TSI students neither agree nor disagree with the statement. The number of students who have a negative evaluation is the same for both groups - only $4 \%$. Sincerity characterises 
the moral and ethics qualities of the brand as well as the attitude of the university towards its students. The data of the research prove that most of the students belonging to both groups believe in their university to be honest towards them. The atmosphere in both universities could be also characterized as positive and inclusive - both universities are accessible and student-oriented.

Another brand personality dimension assessed by the students was excitement. The data show differences in students' opinions. RTU students have given more positive answers than TSI students $-67 \%$ and $47 \%$ agreeing that excitement is characteristic to their university. A bigger number of TSI students have also neither agreed nor disagreed than RTU students - $37 \%$ and $28 \%$. There is also more disagreement expressed by TSI group in comparison with RTU group $-15 \%$ and $5 \%$. Excitement includes three main attributes of the brand - university has to be inspiring, up to date and extraordinary.

Table 2

Distribution of answers according to brand personality dimensions

\begin{tabular}{|l|c|c|c|c|c|c|}
\hline \multirow{2}{*}{ Dimension } & \multicolumn{3}{|c|}{ TSI } & \multicolumn{3}{c|}{ RTU } \\
\cline { 2 - 6 } & agree & $\begin{array}{c}\text { neither agree } \\
\text { nor disagree }\end{array}$ & disagree & agree & $\begin{array}{c}\text { neither agree } \\
\text { nor disagree }\end{array}$ & disagree \\
\hline $\begin{array}{l}\text { Sincerity } \\
\text { (Q1-Q3) }\end{array}$ & $80 \%$ & $15 \%$ & $4 \%$ & $81 \%$ & $16 \%$ & $4 \%$ \\
\hline $\begin{array}{l}\text { Excitement } \\
\text { (Q4-Q6) }\end{array}$ & $47 \%$ & $37 \%$ & $15 \%$ & $67 \%$ & $28 \%$ & $5 \%$ \\
\hline $\begin{array}{l}\text { Ruggedness } \\
\text { (Q7-Q9) }\end{array}$ & $74 \%$ & $20 \%$ & $5 \%$ & $83 \%$ & $13 \%$ & $4 \%$ \\
\hline $\begin{array}{l}\text { Sophistication } \\
\text { (Q10-Q12) }\end{array}$ & $51 \%$ & $38 \%$ & $11 \%$ & $78 \%$ & $19 \%$ & $4 \%$ \\
\hline $\begin{array}{l}\text { Competence } \\
\text { (Q13-Q15) }\end{array}$ & $74 \%$ & $21 \%$ & $5 \%$ & $88 \%$ & $11 \%$ & $1 \%$ \\
\hline
\end{tabular}

The largest difference in the students' opinion was seen evaluating their university to be extraordinary. Only a little more than $20 \%$ of TSI students have agreed with this statement, whereas the number of RTU students was much bigger - more than $55 \%$. RTU provides their students with various and specific study programmes. This fact may explain RTU students' view to characterize their university to be extraordinary. Moreover, the next brand personality attribute assessed by the students was inspiration. The students had to express their opinion if their university could be called as inspiring. The data still 
show difference in the view of both groups. Around $50 \%$ of TSI students have agreed on this attribute, whereas the number of RTU students having given a positive answer is more than $75 \%$. The reason why many RTU students believe in their university to be inspiring as well as extraordinary could be explained by the tendency of this university to develop its student's creativity and thinking "out of the box", in such way setting their minds free and helping them to become more innovative. This fact may also explain the cause why many RTU students have agreed - more than $75 \%$ - to call their university to be up to date in comparison with TSI students - more than $60 \%$.

One more aspect of brand personality dimension analysed in this research was ruggedness. Most of students of both universities have assessed this aspect positively - RTU $(83 \%)$ and TSI $(74 \%)$. Ruggedness reveals several characteristics of the university - if it is open - minded, tolerant and respected. The data prove interesting findings of the research. There are quite similar characteristics of the university the students put emphasis on. Most of TSI students consider their university to be tolerant $-80 \%$, whereas the most of RTU students believe in their university to be respected - almost $85 \%$. Then around $75 \%$ of TSI students call their university to be respected and more than $80 \%$ of RTU students characterize their university to be tolerant. The third attribute - my university is open-minded and has been more highly appreciated by RTU students almost $80 \%$, whereas the students of TSI have evaluated it a little lower - around $70 \%$. Therefore, the data prove that the students of both groups put much emphasis on all three attributes of ruggedness the university has to be tolerant, open-indeed and respected. It is hard to deny that these attributes are very connected because their base lies on the same ground - the respect towards personality. Thus, the key word is the "respect" which should be the main value taken into account by everybody teaching/learning/working at the university. The data prove that this value is present at both universities.

The next brand personality dimension having been analysed in the research is sophistication. The data show that the students of RTU assess this dimension more positively - $78 \%$, whereas TSI students are more critical $-51 \%$. This dimension includes three brand personality attributes - the university has to be upper-class, attractive and innovative. Most of RTU and TSI students have decided to characterize their university to be attractive - more than $80 \%$ of RTU students and almost $60 \%$ of TSI students. This attribute has been selected as the most popular. The second most popular attribute related to sophistication deals with innovation $-80 \%$ of RTU students believe in their university to be innovative, whereas only around $50 \%$ of TSI students agree with it. RTU students are also more positive and certain assessing their university to be 
upper-class one - almost $70 \%$, whereas only a bit more than $40 \%$ of TSI students are of the same opinion. This tendency could be explained with the fact that RTU is one of the biggest universities in Latvia. Therefore, there are more resources to keep its high status and ranking both in Latvia and overseas. However, every university is recommended to become a "modern brand" proving that the innovations lead to attraction and result in an up-todate and upper-class institution.

The last brand personality dimension having been researched is competence. There are three main attributes characterizing the competence of the university - it has to be reliable, intelligent and successful. Most of both group students agree with it $-88 \%$ of RTU students and $74 \%$ of TSI students. Nevertheless, there are more students in TSI group who neither agree nor disagree with these statements $-21 \%$, whereas only $11 \%$ of RTU group do not have a strong opinion. RTU students are also much more certain to evaluate their university to be successful - around $95 \%$ believe in it. However, there is also a high number - $75 \%$ of TSI students who have the same opinion. Thus, both groups of students assessed their university positively showing patriotic feelings about it. When analysing other attributes related to the competence of the university - its reliability and intelligence, RTU group is more favourable - almost $90 \%$ of RTU students call their university to be intelligent and more than $80 \%$ of them evaluate RTU as a reliable institution. TSI students are also positive - around $75 \%$ of them evaluate their university to be reliable and intelligent. Thus, both groups of students believe in the competence of their university being proud of its success.

\section{Conclusions and recommendations}

The following conclusions and recommendations are based on the research results.

- Brand personality is regarded to be one of the central brand management concepts. As everyone has possessed an exclusive identity, each university has its unique brand personality that helps in differentiating this university from others.

- Modern higher education institutions may employ different brand management tools for improving both internal and external branding, including J.L. Aaker's brand personality framework, as the role of brand personality for a university is widely acknowledged.

- In higher education settings, L.L. Aaker's brand personality dimensions epitomized by an assortment of brand attributes associated with a particular university would help higher education marketing managers to understand why students choose a particular university for studies.

- The results of the empirical study demonstrate that every university is recommended to be tolerant, open-minded and respected. The base of it lies on the same ground - the respect towards the personality.

- Furthermore, every university is also recommended to become a "modern brand", innovation, creativity and thinking "out of the box" being essential characteristics of the brand.

- In the main, students of both universities perceive their brands' personality positively, which might be indicative of the fact that the above universities have a well-developed marketing strategy aimed at building a strong university brand and focused on the current and prospective students.

- The results of the study are supposed to contribute to overall understanding of brand personality in higher education, and how it may influence preference for a brand in educational settings; this is important for developing an efficient marketing and student recruitment strategy.

- However, further research is recommended to generalize the findings; it would help refine the university brand personality scale and make it more universal.

\section{Bibliography}

1. Aaker D.A. (2011). Building Strong Brands. NY: The Free Press.

2. Aaker D.A. (2012). Win the Brand Relevance Battle and Then Build Competitor Barriers. California Management Review, 54(2), 43-57. doi: 10.1525/cmr.2012.54.2.43

3. Aaker J.L. (1997). Dimensions of Brand Personality. Journal of Marketing Research, 34(3), 347-356. doi: $10.2307 / 3151897$

4. Aaker D.A., Joachimsthaler E. (2012). Brand Leadership. NY: The Free Press.

5. Aaker D.A., Keller K.L. (1990). Consumer Evaluations of Brand Extensions. Journal of Marketing, 54(1), 27-41. doi: 10.1177/002224299005400102 
6. Chapleo C. (2010). What Defines "Successful" University Brands? International Journal of Public Sector Management, 23(2), 169-183. doi: 10.1108/09513551011022519

7. Clark P., Chapleo C., Suomi K. (2020). Branding Higher Education: An Exploration of the Role of Internal Branding on Middle Management in a University Rebrand. Tertiary Education Management, 26, 131-149. doi: 10.1007/s11233-019-09054-9

8. Davies G., Rojas-Mendez J.I., Whelan S., Mete M., Loo T. (2018). Brand Personality: Theory and Dimensionality. Journal of Product \& Brand Management, 27(2), 115-127. doi: 10.1108/JPBM-062017-1499

9. Hemsley-Brown J., Melewar T.C., Nguyen B., Wilson E.J. (2016). Exploring Brand Identity, Meaning, Image, and Reputation (BIMIR) in Higher Education: A Special Section. Journal of Business Research, 69(8), 3019-3022. doi: 10.1016/j.jbusres.2016.01.016

10. Hemsley-Brown J., Oplatka I. (2006). Universities in a Competitive Global Marketplace. International Journal of Public Sector Management, 19(4), 316-338. doi: 10.1108/09513550610669176

11. Keller K.L. (1993). Conceptualizing, Measuring, and Managing Customer-Based Brand Equity. Journal of Marketing, 57(1), 1-22. doi: 10.1177/002224299305700101

12. Keller K.L. (2001). Building Customer-Based Brand Equity: A Blueprint for Creating Strong Brands. Cambridge/MA, USA: Marketing Science Institute. Retrieved from http://mktg.unisvishtov.bg/ivm/resources/CustomerBasedbrandEquityModel.pdf

13. Keller K.L. (2007). Advertising and Brand Equity. In G.J. Tellis, T. Ambler (Eds.), The SAGE Handbook of Advertising, London: Sage Publications, 54-70. doi: 10.4135/9781848607897

14. Keller K.L. (2008). Strategic Brand Management: Building, Measuring, and Managing Brand Equity ( $3^{\text {rd }}$ ed.). Upper Saddle River, NJ: Prentice Hall.

15. Keller K.L. (2009). Building Strong Brands in a Modern Marketing Communications Environment. Journal of Marketing Communications, 15(2-3), 139-155. doi: 10.1080/13527260902757530

16. Keller K.L. (2013). Strategic Brand Management: Building, Measuring, and Managing Brand Equity. (Global ed.). England: Pearson Education Limited.

17. Kotler Ph., Keller K.L. (2012). Marketing Management (14 $4^{\text {th }}$ ed.). UK: Pearson.

18. Kotler Ph., Keller K.L. (2016). A Framework for Marketing Management ( $6^{\text {th }}$ ed.). UK: Pearson.

19. Low G.S., Lamb Jr. Ch.W. (2000). The Measurement and Dimensionality of Brand Associations. Journal of Product \& Brand Management, 9(6), 350-368. doi: 10.1108/10610420010356966

20. Mampaey J., Huisman J. (2016). Branding of UK Higher Education Institutions. An Integrated Perspective on the Content and Style of Welcome Addresses. Recherches Sociologiques et Anthropologiques, 47(1), 133-148. doi: 10.4000/rsa.1636

21. Maringe F. (2006). University and Course Choice: Implications for Positioning, Recruitment and Marketing. International Journal of Educational Management, 20(6), 466-479. doi: 10.1108/09513540610683711

22. Plummer J.T. (2000). How Personality Makes a Difference. Journal of Advertising Research, 40(6), 79-83. doi: 10.2501/JAR-40-6-79-83

23. Roskosa A., Stukalina Y. (2018). Management of a Study Programme in the Context of Quality Assurance in Higher Education. In V. Dislere (Ed.), The Proceedings of the International Scientific Conference Rural Environment. Education. Personality (REEP), 11. Jelgava: LLU, 118-127. doi: 10.22616/REEP.2018.014

24. Roskosa A., Stukalina Y. (2020). Investigating Students' Perceptions of their University's Brand. In V. Dislere (Ed.), The Proceedings of the International Scientific Conference Rural Environment. Education. Personality (REEP), 13. Jelgava: LLU, 123-133. doi: 10.22616/REEP.2020.015

25. Stensaker B., D'Andrea V. (2007). Branding - the Why, What and How. In B. Stensaker, V. D'Andrea (Eds.), Branding in Higher Education. Exploring an Emerging Phenomenon. Amsterdam: Eair 6-13.

26. Stukalina, Y. (2019). Strategic Brand Positioning in a Modern Academia. The European Proceedings of Social \& Behavioural Sciences, 71, 20-29. doi: 10.15405/epsbs.2019.10.02.3

27. Tong X., Su J., Xu Y. (2018). Brand Personality and Its Impact on Brand Trust and Brand Commitment: An Empirical Study of Luxury Fashion Brands. International Journal of Fashion Design, Technology and Education, 11 (2), 196-209. doi: 10.1080/17543266.2017.1378732

28. Wæraas A., Solbakk M. (2009). Defining the Essence of a University: Lessons from Higher Education Branding. Higher Education, 57, 449-462. doi: 10.1007/s10734-008-9155-z

29. Wu T., Naidoo V. (2016). The Role of International Marketing in Higher Education. In T. Wu, V. Naidoo (Eds.), International Marketing of Higher Education, NY: Palgrave Macmillan, 3-9. doi: 10.1057/978-1-137-54291-5_1 